\title{
Development of B2C e-commerce in the European Union countries
}

\author{
Развој В2С модела е-трговине у земљама \\ Европске уније \\ тања Текић ${ }^{*}$ \\ JT International, Београд
}

\begin{abstract}
Development of B2C e-commerce can be reviewed from different perspectives, using various data and predicting conclusions based on them. The topic of this paper is to explain development of B2C e-commerce in the European Union countries. Collected are data from third, in depended side which is showing the percentage of e-retailers from EU countries that are selling products and services on the B2C market. Observed countries can be grouped together into clusters, but differences between them and development trend are obvious. Counties with the similar socio - economic development within the same clusters have differences between $\mathrm{B} 2 \mathrm{C}$ e-commerce developments.
\end{abstract}

Keywords: B2C, e-commerce, European Union

Сажетак: У разумијевању и сагледавању развоја В2C е-трговине могуће је узети у обзир различите показатеље и донијети различите закључке. Тема овог рада јесте В2С е-трговина, односно њен развој у земљама чланицама Европске уније. Прикупљени су подаци треће, ненадлежне стране, о проценту В2С е-малопродаваца који продају производе и услуге у земљама Европске уније. Посматране земље могу се међусобно груписати, али постоје разлике у развоју и трендовима развоја, чак и међу земљама које припадају истим кластерима и имају сличне нивое социо-економског развоја.

Кључне речи: В2С, е-трговина, Европска унија.

\section{Introduction}

The emergence of new marketing channels is important to the customer and enables the rapid growth and development of $\mathrm{B} 2 \mathrm{C}$ e-commerce. Consumers have the opportunity to choose from a large number of retailers, their products, do price comparison, alternatives comparison, collect various information, but also communicate with sellers and personalize the services and products needed. Electronic commerce is experiencing the prosperity over the last decades, but what is even more important is that it is developing also in our country in recent years, and has an increasingly important role.

If we look at Europe, western countries are more developed, retailers within them already have integrated a few channels, multi or omni channel retailing. In this paper, focus will be on the percentage of retailers who sell products electronically to

${ }^{*} \bowtie$ tanjatekic@gmail.com 
end-users within the European Union, with the aim of discovering the differences between countries and future development trends.

The paper will be divided into three parts; the first will consist of a theoretical overview of the available literature and already present trends and data on $\mathrm{B} 2 \mathrm{C}$ ecommerce in the countries of the European Union. Members of the Union are some of the most developed countries of the world, but there are differences between them. The next part of the paper will consist of the description of the used data, the set of research hypotheses and the methodology used for data processing and reaching the results. In the third part of the paper, the obtained results and a discussion of the same will be presented in order to solve the hypotheses and problems of work.

\section{Literature review}

Although retailers' business today cannot be imagined without e-commerce and communication with customers, it has gone a long way since its beginnings from several decades ago. E-commerce primarily involved distribution, purchase, sales, marketing and services through the use of e-systems such as the Internet and other computing networks; now, it also includes electronic money transfer, supply chain management, e-marketing, electronic information exchange and automatic collection system data (Raut, Mitrović, Melović, \& Rondović, 2017). The emergence of the Internet and ecommerce enables two-way communication between the seller and the customer, the customers' needs and desires surveying and a fast way to carry out the process of purchasing and distributing products. Business-to-Consumer - B2C electronic commerce includes all business transactions between business entities and consumers (Lovreta, Končar \& Petković, 2013). B2C e-commerce has influenced the changing habits of con-sumers who are increasingly searching the product online, its specifications, substitute, compare it to a few sellers and then make a purchase decision. The Internet has encouraged customers in three ways: when making purchasing decisions, during the purchase and through product ownership, including the delivery, maintenance and return of the same (PwC, 2012). Buyers do not make decisions without first checking the product online, but still the most common style of purchases is in objects with a phys-ical location, where they can see the quality and performance they have previously read about. "Look online, buy in the store" is the term derived from two primary consumer needs: efficiency and reliability (Berman, \& Evans, 2010). From the standpoint of retailers, this kind of business has led to significant changes in the distribution of power in marketing channels. Putting the consumers in forefront, along with technology developments is leading to the strengthening of retailers who have become leaders in the marketing channel.

They communicate directly with customers and know their habits, needs and desires. With the entrance of the $\mathrm{B} 2 \mathrm{C}$ market, retailers have to make the customer's experience flawless in every contact, maximize sales across each channel and device, and fulfill promises in terms of delivery and availability in order to create a strong 
retail brand for consumers to return to; shopping must be "Retail Therapy" - effortless, relaxing and comfortable (Enterprise Europe Network, 2018). New technological solutions, advancements in e-commerce, its growth, the development of multichannel, omni-directional and other forms of sales and communication with consumers are a great opportunity for all retailers, especially large with significant capital, to perform globally. The e-commerce market, through the sale of products and services on the Internet, strives for the complete globalization of the B2B and B2C electronic commerce market (Končar, \& Katai Petrović, 2009). The B2C market is gaining on importance because the buyer can buy from overseas and compare a variety of products from different retailers of different origins. Large e-retailers are growing and their importance in all countries is rising, while locals are introducing new channels and using their benefits, and expect to develop existing and new e-channels in the future. Selling online in the e-market is a great way to (Enterprise Europe Network, 2018):

- Provide an additional sales channel on the market and product sales,

- Build a customer base in another country,

- Increase the exposure of brands and products in other countries,

- Tests the demand for a new market,

- Ensure the trust of a new brand / product by consumers,

- Potentially provide a market route with lower costs with fewer risks,

- Offer local experience - local currency, payment methods, delivery methods and compliance with local conditions,

- Communicate with local customers and avoid misunderstanding in translationbased communication,

- Help consumers look at standard product specifications, compare them and compare each other on a single platform,

- Ensure higher transparency in the ordering process, in terms of availability, price and level of inventory.

These advantages are the reason for the expansion and development of electronic trade in recent years. More and more retailers perform internationally and operate globally, without borders, time and spatial frameworks, but respecting local regulations and taking all risks. Observing the global market and trends from the end of 2017, the following facts about the development of e-commerce and the $\mathrm{B} 2 \mathrm{C}$ model (Ecommerce foundation, 2017) are noted:

- Europe has the highest e-GDP (4.9\%),

- The Asia-Pacific region has a share of $47.5 \%$ in total B2C traffic, while Europe accounts for $25.6 \%$, and North America with $24.9 \%$

- China B2C dominates the volume of sales ( $\$ 682$ billion), followed by the UK ( $\$$ 438 billion), 
- The share of consumers using mobile devices has increased by $50 \%$ compared to 2016,

- Amazon is the largest global e-retailer, but Apple is the most valuable,

- PCs and laptops are still devices that account for around $60 \%$ in total e-sales in all regions,

- The most popular social network used for e-commerce is Facebook, etc.

Europe is one of the most developed markets and a market within which ecommerce is turning around; there are differences in the level of development between the regions and countries, but also the EU members themselves. Western Europe's markets are advanced in terms of Internet and online penetration of customers. In 2015, 8 countries in the region had a percentage of over $90 \%$ of Internet users, and 4 had online penetration of customers with over $80 \%$ of Internet users (Yelken, 2016). The Western European market consists of more developed and financially independent countries, with an exceptionally high level of economic development and e-literacy of the inhabitants. The most developed markets with the highest percentage of online customers and the highest income of B2C e-commerce are UK, Germany and France (E-commerce Foundation, 2017). Unlike the North American and Asia-Pacific regions where there are dominant, global retailers who occupy the largest share of the electronic market in Europe are dominant domestic retailers and their importance grows.

Looking at $2017,33 \%$ of customers decided to order their products from abroad, while the percentage of those who order from domestic e-troubles is still dom-inant by $49 \%$ and grew 2\% from last year (E-commerce Foundation, 2017). The growth of ecommerce and the changes that are taking place in all European markets are huge, rates, growth rates are two-digit, but similar to retail, large systems are in-vesting enormous resources and generating high turnover and are still market leaders.

The value achieved on the European continent in B2C ecommerce in 2016 was \$ 531 billion, while estimates for 2017 amounted to as much as $\$ 603$ billion, and the growth rate is double digit, but slows down in relation to historical trends (E- com-merce Foundation, 2017). The largest e-retailer in Europe is Amazon with 38.5 billion euros of sales and sales growth of almost $21 \%$ in the period 2012-2015. The list of top 15 European e-retailers includes companies from 5 countries, 9 from UK and 3 from Germany. The highest growth in Internet traffic in Western Europe in the period 2012 2015 was achieved by the Swiss Migros (growth of 67\%).

Table 1. Companies with the highest online turnover in Europe in 2015

\begin{tabular}{|l|c|c|c|}
\hline Company & Country of origin & $\begin{array}{c}\text { Online turnover in } \\
\text { Europe (2015, } \\
\text { billions of euros) }\end{array}$ & $\begin{array}{c}\text { Internet sales } \\
\text { changes: West } \\
\text { Europe 2012-2015* }\end{array}$ \\
\hline Amazon & Germany & 38.5 & $20.9 \%$ \\
\hline Zalando & Germany & 2.3 & $25.7 \%$ \\
\hline
\end{tabular}


Development of B2C e-commerce in the European Union coun-

\begin{tabular}{|l|c|c|c|}
\hline John Lewis & UK & 2.1 & $23.4 \%$ \\
\hline Yoox Net-A-Porter-Group & UK & 1 & $23 \%$ \\
\hline Cdiscount/Groupe Casino & France & 2.4 & $21.9 \%$ \\
\hline Next & UK & 2.2 & $15.7 \%$ \\
\hline Apple & UK & 6.4 & $17.3 \%$ \\
\hline Metro Group & Germany & 1.6 & $17 \%$ \\
\hline ASOS & UK & 1 & $34.3 \%$ \\
\hline Ocado & UK & 1.4 & $15.3 \%$ \\
\hline Dixons Carphone & UK & 3.9 & $8.8 \%$ \\
\hline Migros & Switzerland & 1 & $67 \%$ \\
\hline J Sainsbury & UK & 1.7 & $10.4 \%$ \\
\hline Royal Ahoid & Netherlands & 1.1 & $17.1 \%$ \\
\hline Home Retail Group & UK & 1 & $9.4 \%$ \\
\hline \hline
\end{tabular}

Source: E-commerce foundation, 2017

The following graph shows retailers who were a choice of European customers when buying products from abroad. Similar to the global trends, Amazon and Alibaba / Aliexpress groups are the leaders followed by other e-retailers.

Graph 1. B2C European e-retailers by participating share in online sales outside domicile borders

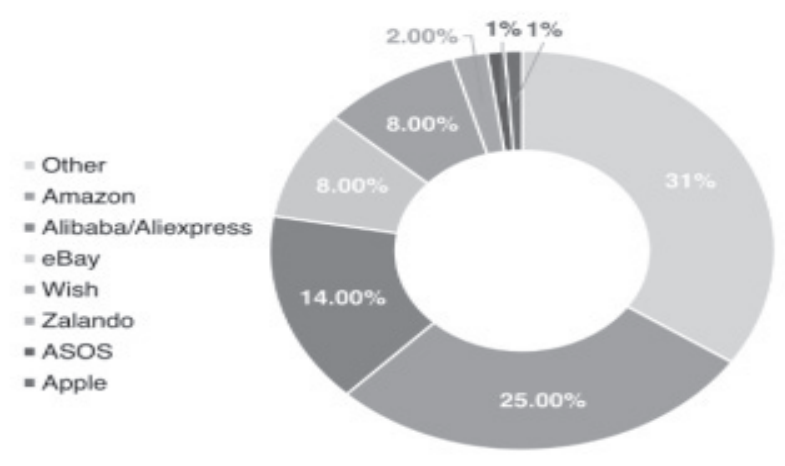

Source: Euro Commerce foundation, 2018

The development of e-commerce, and in particular the $\mathrm{B} 2 \mathrm{C}$ model, shows significant growth rates in all of the European countries. However, the development 
trends and the significance of national economies and their development come to light and there is a difference in development between the countries of Europe. Western Europe is dominant as the richest and most important area; however, within the countries of the European Union, the growth of B2C e-commerce is developing at a high speed, which was the reason for the research presented in this paper.

\section{Data, hypothesis and methodology}

By looking at the basic concepts of e-commerce, development and growth trends in last several decades in our region and the environment, as well as by looking at global development data, collected is data on the percentage of e-retailers from EU countries that are selling products and services on the $\mathrm{B} 2 \mathrm{C}$ market. The data is collected from the third, direct side and are available online. They are available for periods from 2010 to 2017. Followed are the dynamics and trends in the movement of percentages of eretailers of the observed 28 countries in that period.

Table 2. Percentage of retailers with B2C e-sales by countries of the European Union in the period 2010 - 2017

\begin{tabular}{|c|c|c|c|c|c|c|c|c|}
\hline Country/Year & 2010 & 2011 & 2012 & 2013 & 2014 & 2015 & 2016 & 2017 \\
\hline Belgium & 29 & 27 & 24 & 21 & 24 & 26 & 26 & 26 \\
\hline Bulgaria & 4 & 6 & 7 & 7 & 9 & 9 & 9 & 10 \\
\hline Czech Republic & 21 & 27 & 26 & 27 & 28 & 25 & 27 & 24 \\
\hline Denmark & 29 & 28 & 29 & 30 & 28 & 27 & 29 & 30 \\
\hline Germany & 24 & 22 & 24 & 26 & 25 & 27 & 28 & 26 \\
\hline Estonia & 11 & 12 & 13 & 13 & 14 & 15 & 18 & 19 \\
\hline Iceland & 21 & 23 & 23 & 23 & 27 & 32 & 30 & 33 \\
\hline Greece & 9 & 9 & 9 & 10 & 10 & 7 & 12 & 12 \\
\hline Spain & 13 & 12 & 14 & 14 & 18 & 18 & 21 & 21 \\
\hline France & 14 & 13 & 14 & 14 & 15 & 21 & 21 & 21 \\
\hline Croatia & 24 & 22 & 27 & 21 & 27 & 20 & 19 & 18 \\
\hline Italy & 5 & 5 & 6 & 8 & 8 & 10 & 11 & 13 \\
\hline Cyprus & 7 & 8 & 8 & 8 & 12 & 11 & 13 & 13 \\
\hline Latvia & 7 & 9 & 9 & 10 & 9 & 10 & 10 & 12 \\
\hline Lithuania & 22 & 25 & 17 & 22 & 19 & 19 & 20 & 23 \\
\hline Luksemburg & 15 & 18 & 16 & 17 & 13 & 10 & 15 & 13 \\
\hline Hungary & 9 & 12 & 12 & 13 & 13 & 14 & 15 & 16 \\
\hline Malta & 17 & 19 & 18 & 18 & 19 & 19 & 20 & 19 \\
\hline Netherlands & 24 & 24 & 20 & 22 & 24 & 25 & 25 & 26 \\
\hline Austria & 18 & 15 & 16 & 16 & 17 & 18 & 19 & 21 \\
\hline Poland & 9 & 10 & 11 & 11 & 12 & 12 & 12 & 12 \\
\hline Portugal & 19 & 16 & 15 & 15 & 15 & 20 & 19 & 18 \\
\hline Romania & 6 & 4 & 5 & 10 & 8 & 8 & 7 & 8 \\
\hline
\end{tabular}




\begin{tabular}{|c|c|c|c|c|c|c|c|c|}
\hline Slovenia & 12 & 13 & 16 & 15 & 18 & 22 & 20 & 25 \\
\hline Slovakia & 8 & 16 & 14 & 20 & 15 & 15 & 15 & 18 \\
\hline Finland & 19 & 21 & 21 & 19 & 19 & 19 & 22 & 24 \\
\hline Sweden & 25 & 26 & 27 & 26 & 26 & 28 & 28 & 31 \\
\hline United Kingdom & 17 & 19 & 21 & 22 & 22 & 23 & 22 & 23 \\
\hline
\end{tabular}

Source: Euro Stat, Retrieved from http://ec.europa.eu/, on 10.06.2018.

For the purpose of research, in order to answer the problem of work, the following hypotheses have been set:

H1: There is no statistically significant difference in the percentage of retailers who have e-sales on the B2C market within the countries of the European Union.

$\mathrm{H} 2$ : The percentage of retailers with e-sales on the $\mathrm{B} 2 \mathrm{C}$ market is still growing in all countries of the union.

H3: Based on the trend of development of percentages of e-commerce retailers on the $\mathrm{B} 2 \mathrm{C}$ market in the countries of the European Union can be clustered into clusters.

$\mathrm{H} 4$ : Between the defined clusters there are no statistically significant differences in the development of the percentage of retailers with e-sales on the $\mathrm{B} 2 \mathrm{C}$ market.

H5: Between and within the cluster there are no statistically significant differences between the percentages of retailers with e-sales on the EU's B2C market.

Several statistical methods and indicators were used for processing and analysis of data, including descriptive statistics, variances, correlations, cluster methods, etc.

\section{Results}

The explanation from the previous sections, even without statistical processing brings us to the conclusion that the percentage of retailers who have e-sales on the $\mathrm{B} 2 \mathrm{C}$ market in the countries of the European Union is growing. The available data show the dynamics from 2010 to 2017, which will be in the focus of further research and response to hypotheses.

The first hypothesis relates to the statistical differences between the country of the Union and the percentage of retailers with e-sales on the B2C market. Using the $\mathrm{t}$ test where the ratio of the country and the value of the percentages from 2017, we obtained the result of test 46.2 , the difference $p=0.00$, which concludes that there are statistically significant differences between the observed variables and we reject the first hypothesis. Average percentage of e-commerce retailers in the countries is $19.8 \%$. 
Table 3. Display of t-values - test of observed variables

\begin{tabular}{|c|c|c|c|c|c|c|c|c|c|c|}
\hline & $A v g$ & Std.Dev. & $N$ & $\begin{array}{c}\text { Differe } \\
\text { nce }\end{array}$ & $\begin{array}{c}\text { Std. } \\
\text { Dev. - } \\
\text { Differe } \\
\text { nce }\end{array}$ & $t$ & $d f$ & $p$ & $-95.0 \%$ & $+95.0 \%$ \\
\hline Country & 114.5000 & 8.225975 & & & & & & & & \\
\hline $\begin{array}{l}2017 \% \text { of } \\
\text { retailers with e- } \\
\text { commerce }\end{array}$ & 19.8214 & 6.633549 & 28 & 94.67 & 10.84 & 46.19 & 27 & 0.00 & 90.47 & 98.88 \\
\hline
\end{tabular}

Source: Author

The next hypothesis refers to the trend of growth in retail sales with e-sales on the $\mathrm{B} 2 \mathrm{C}$ market within all countries. If the correlation between countries and the percentage of retailers with e-sales in 2017 is compared with 2010, the average percentage is $4.2 \%$. At the level of all 28 countries, the average percentage is rising, while the correlation of 0.82 is strong and significant. However, in the case of isolated countries with a lower percentage of e-commerce retailers in the B2C market, such are Belgium, Croatia, Luxembourg and Portugal, which, in addition to the average growth at Union level, leads to the second hypothesis of rejection, and we conclude that in some countries the percentage of these retailers decreases over the years.

Table 4. Display of correlation values of observed variables

\begin{tabular}{|c|c|c|c|c|}
\hline & $A v g$ & Std. Dev. & $\begin{array}{l}2010 \% \text { of } \\
\text { retailers wih } \\
\text { e-commerce }\end{array}$ & $\begin{array}{l}2017 \% \text { of } \\
\text { retailers wih e- } \\
\text { commerce }\end{array}$ \\
\hline $2010 \%$ of retailers wih e-commerce & 15.64286 & 7.479425 & 1.000000 & 0.816070 \\
\hline $2017 \%$ of retailers wih e-commerce & 19.82143 & 6.633549 & 0.816070 & 1.000000 \\
\hline
\end{tabular}

Source: Author

After grouping the countries of the European Union according to the percentage of retailers with e-sales on the $\mathrm{B} 2 \mathrm{C}$ market and setting the Linkage distance limit to $11 \%, 4$ clusters were obtained and the third hypothesis was confirmed:

1. The cluster consists of: Czech Republic, Spain, France, Lithuania, Austria, Slovenia, Finland and the UK,

2. The cluster consists of: Estonia, Croatia, Malta, Portugal and Slovakia,

3. The cluster consists of: Belgium, Germany, Denmark, Iceland, the Netherlands and Sweden,

4. The cluster consists of: Bulgaria, Greece, Cyprus, Italy, Latvia, Luxembourg, Romania and Poland. 
Graph 2. Dendogram, presentation of clusters of EU grouped countries according to the percentage of retailers with e-sales on the B2C market

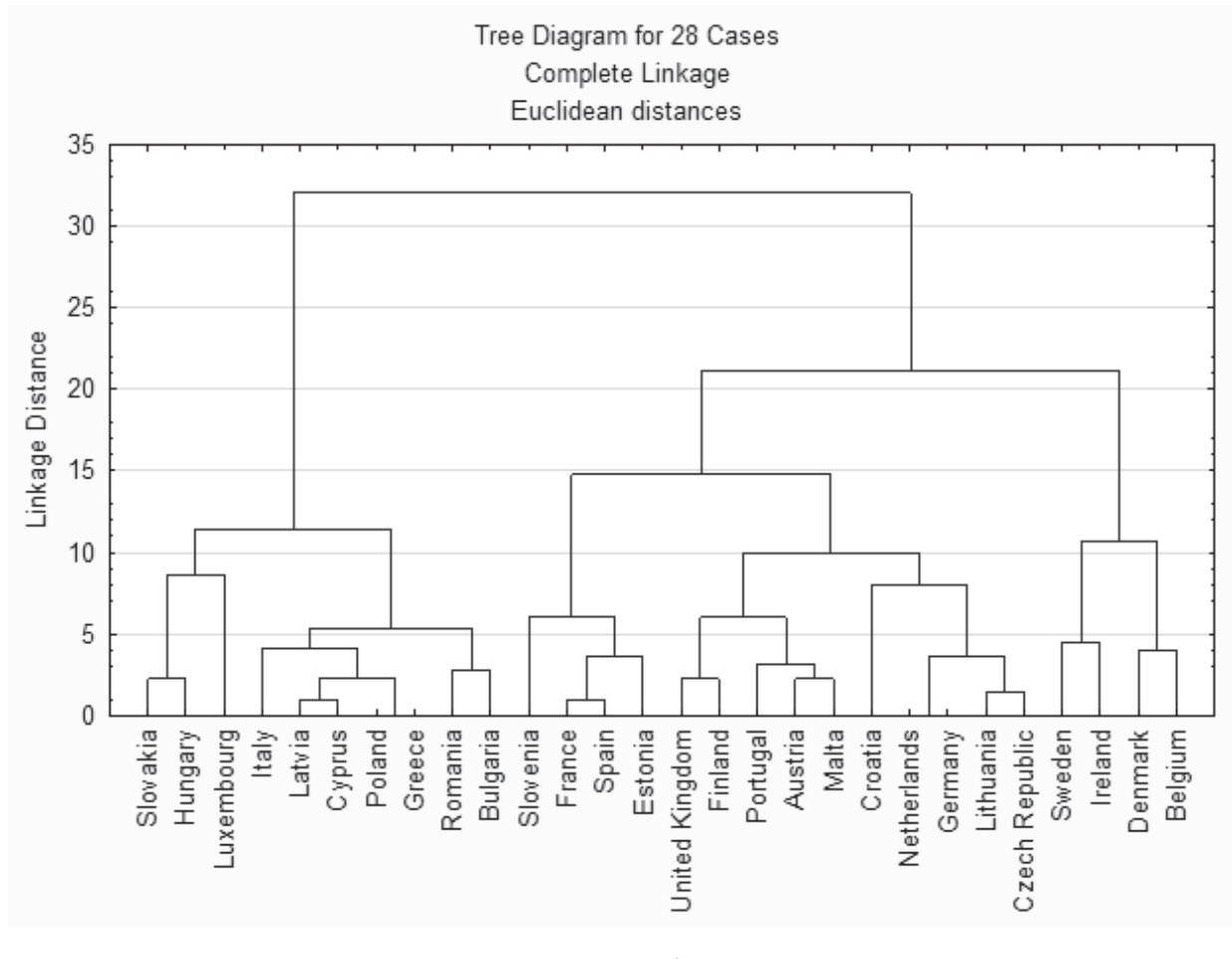

Source: Author

The clusters and the countries within them have a different level of achieved development, socio-economic, demographic and other characteristics. However, clusters according to the tested version, the percentage of e-commerce retailers on the B2C market have group averages, and the third cluster average, $22.75 \%$ of sellers with e-sales in 2017 have the highest percentage. The fourth-cluster countries have the lowest percentage of average e-commerce sellers of $11.625 \%$ and these are lowdevelopment level member countries if we look at their names within the cluster.

Table 5. Display of average values within the cluster according to data from 2017

\begin{tabular}{|c|c|c|c|c|}
\hline \multicolumn{5}{|c|}{ Cluster Averages } \\
\hline & Cluster 1 & Cluster 2 & Cluster 3 & Cluster 4 \\
\hline $2017 \%$ of retailers with e-commerce & 22.75000 & 18.00000 & 28.66667 & 11.62500 \\
\hline
\end{tabular}

Source: Author 
The following table shows the differences between defined clusters, done via Euclidean distance. We see that the distance of the third calster, where we can find the largest average percentage of retailers with e-sales, is significantly different and is far from the fourth and second clusters.

Table 6. Differences, distance between clusters

\begin{tabular}{|c|c|c|c|c|}
\hline \multicolumn{5}{|c|}{$\begin{array}{l}\text { Euclidean Distance between clusters } \\
\text { Squared distance }\end{array}$} \\
\hline & Cluster 1 & Cluster 2 & Cluster 3 & Cluster 4 \\
\hline Cluster 1 & 0.00000 & 22.56250 & 35.0069 & 123.7656 \\
\hline Cluster 2 & 4.75000 & 0.00000 & 113.7778 & 40.6406 \\
\hline Cluster 3 & 5.91667 & 10.66667 & 0.0000 & 290.4184 \\
\hline Cluster 4 & 11.12500 & 6.37500 & 17.0417 & 0.0000 \\
\hline
\end{tabular}

Source: Author

The fourth hypothesis argues that there are no statistically significant differences in the development of the percentage of retailers with e-sales on the B2C market, which we tested together with the subsequent use of the variance analysis. To test the last hypothesis, the differences between and within the clusters, the percentage of retailers with e-sales on the $\mathrm{B} 2 \mathrm{C}$ market of the European Union was used to analyze the variance.

Table 7. Analysis of variance analysis and cluster differences

\begin{tabular}{|c|c|c|c|c|c|c|}
\hline \multicolumn{7}{|c|}{ Variance analysis } \\
\hline & $\begin{array}{c}\text { Between - } \\
\text { SS }\end{array}$ & $d f$ & $\begin{array}{l}\text { Within- } \\
\text { SS }\end{array}$ & $d f$ & $F$ & Significance- $p$ \\
\hline $\begin{array}{c}2017 \% \text { of retailers } \\
\text { with e-commerce }\end{array}$ & 1095.399 & 3 & 92.70834 & 24 & 94.52430 & 0.000000 \\
\hline
\end{tabular}

Source: Author

The obtained values of $\mathrm{F}$ and $\mathrm{p}$ from the table show that there are statistically significant differences between both, between and within the cluster, which reject this hypothesis. The difference between the European Union countries from the percentage of retailers who use the advantages of e-sales on the $\mathrm{B} 2 \mathrm{C}$ market exists and is significant, there is also a difference between countries within the same clusters, with a similar degree of development of B2C e-retail.

\section{Conclusion}

The development of new technologies, media, communication modes and consumer behavior changes have imposed a need for investment in e-commerce, online business and consumer communication. Electronic commerce is developing for several decades, 
as a result of its development, we have the fact that an increasing number of retailers have a multi-channel strategy of selling. European countries are significantly different in terms of the development of e-commerce, which is most often associated with the degree of economic and social development of each of them. Retailers in developed countries (UK, Germany, France, etc.) make significant revenues and a large part of their sales online.

B2C e-commerce is developing and Europe is the second region according to the value of realized revenues from a part of the market, immediately after the Asia-Pacific region. In the past year, B2C e-retailers in Europe have generated over 600 billion dollars of turnover, mostly in the most developed Western countries - UK, Germany and France. What sets Europe apart, especially the countries of the European Union from the rest of the world, is the fact that $50 \%$ of orders have been ordered from local retailers, despite exceptionally strong competition. It is precisely because of this fact that the trend of development of the percentage of retailers who have e-sale on the $\mathrm{B} 2 \mathrm{C}$ market in the countries of the European Union was observed in this study.

After analyzes, it was concluded that there are statistically significant differences between the 28 countries of the Union, that the development trend is not the same in all countries. In some countries (Belgium, Croatia, Portrugal and Luxembourg), despite the growth in e-sales and revenues generated by this mode of sales, there is a decline in the percentage of retailers with e-sales on the $\mathrm{B} 2 \mathrm{C}$ market. The result of this decline is that foreign e-retailers are very competitive and in these countries slowly occupy a place of domicile. The countries can be grouped together in four clusters, which differ from one another. Clusters are made up of countries of a similar degree of development of e-commerce and the observed variables of the percentage of retailers who have e-sales on the $\mathrm{B} 2 \mathrm{C}$ market, but also the development of the economy, social characteristics, etc. In addition to the fact that the observed countries are similar within the cluster, there are statistically significant differences in the percentage of $\mathrm{B} 2 \mathrm{C}$ e-retailers.

\section{References}

Berman, B., \& Evans, J. (2010). Retail Managament: A strategic approach - eleventh edition. New Jersey: Pearson Education

E-commerce foundation. (2017). European E-commerce Report 2017. Retrieved June 22nd, 2018, from https://www.eurocommerce.eu/media

E-commerce foundation. (2017). Global E-commerce Report 2017. Retrieved June

22nd, 2018, from https://www.eurocommerce.eu/media

Enterprise Europe Network. (2018). A guide to e commerce in Europe. Retrieved June 21st, 2018, from https://een.ec.europa.eu 
Euro Commerce foundation. (2018). The European B2C Ecommerce Report 2018. Retrieved July 16th, 2018, from https://www.adigital.org,

Euro Stat. Retrieved June 10th, 2018, from http://ec.europa.eu/

Končar, J., \& Katai Petrović, Z. (2009). Pravci razvoja elektronske trgovine u Republici Srbiji. Retrieved June 18th, 2018, from http://yuinfo.artkey.rs/zbornici/2009/html/pdf/024.pdf

Lovreta, S., Končar, J.,\& Petković, G. (2013). Kanali marketinga: trgovina i ostali kanali. Beograd: CID, Ekonomski fakultet, Univerzitet u Beogradu i Ekonomski fakultet Subotica, Univerzitet u Novom Sadu.

PwC. (2012). Understanding how US online shoppers are reshaping the retail experience. Retrieved June 20th, 2018, from www.pwc.com/structure

Raut, J., Mirtrović, S., Melović, B., \& Rondović, B. (2017). E - commerce as a model for entrepreneurship. XVII International Scientific Conference on Industrial Systems, University of Novi Sad, Faculty of Technical Sciences

Yelken, Y. (2016). Western Europe's share of global B2C E-Commerce to decline. Retrieved June 22nd, 2018, from https://www.linkedin.com/pulse/western-europesshare-global-b2c-e-commerce-decline-yuecel-yelken

\section{Summary}

The paper is reasarch about B2C development of B2C e-commerce in the European Union countries based on precentage of retailers selling prodcuts that way. Theoretical overview is knowlagde based on latest trends and papers, reports avaliable in the previous years. EU countries can be clusterized from the persepctive of the percentage of retailers who have e-commerce on the $\mathrm{B} 2 \mathrm{C}$ market, but even within clusters differences are significant between countries. Trends of historical and future development are noticed and explained. 